\title{
Urakami Memory and the Two Popes: The Disrupting of an Abstracted Nuclear Discourse
}

\author{
Gwyn McClelland (D)
}

check for

updates

Citation: McClelland, Gwyn. 2021. Urakami Memory and the Two Popes: The Disrupting of an Abstracted Nuclear Discourse. Religions 12: 950. https://doi.org/10.3390/rel12110950

Academic Editors: Yuki Miyamoto and Susumu Shimazono

Received: 27 September 2021

Accepted: 27 October 2021

Published: 1 November 2021

Publisher's Note: MDPI stays neutral with regard to jurisdictional claims in published maps and institutional affiliations.

Copyright: (C) 2021 by the author. Licensee MDPI, Basel, Switzerland. This article is an open access article distributed under the terms and conditions of the Creative Commons Attribution (CC BY) license (https:/ / creativecommons.org/licenses/by/ $4.0 /)$.
Department of Languages, Literatures, Linguistics, and Cultures, University of New England, Armidale 2350, Australia; gwyn.mcclelland@une.edu.au

\begin{abstract}
Since 1945, official Catholic discourse around nuclear weapons has condemned their existence on the one hand and supported them as deterrents on the other. This paper argues the largely abstracted discourse on nuclear weapons within the World Church has been disrupted by voices of Urakami in Nagasaki since at least 1981, as the Vatican has re-considered both memory and Catholic treatments of the bombing of this city since the end of World War II. On 9 August 1945, a plutonium A-bomb, nicknamed 'Fat Man', was detonated by the United States over the northern suburb of Nagasaki known as Urakami. Approximately 8500 Catholics were killed by the deployment of the bomb in this place that was once known as the Rome of the East. Many years on, two popes visited Nagasaki, the first in 1981 and the second in 2019. Throughout the period from John Paul II's initial visit to Pope Francis's visit in 2019, the Catholic Church's official stance on nuclear weapons evolved significantly. Pope John Paul II's contribution to the involvement in peace discourses of Catholics who had suffered the bombing attack in Nagasaki has been noted by scholars previously, but we should not assume influence in 1981 was unidirectional. Drawing upon interviews conducted in the Catholic community in Nagasaki between 2014 and 2019, and by reference to the two papal visits, this article re-evaluates the ongoing potentialities and concomitant weaknesses of religious discourse. Such discourses continue to exert an influence on international relations in the enduring atomic age.
\end{abstract}

Keywords: Catholic; pope; history; oral history; atomic weapons; nuclear weapons; bombing; abstract; United States; Nagasaki

\section{Introduction}

The Catholic Church's official position on nuclear weapons throughout the atomic era has evolved from a tacit acceptance of deterrence during the Cold War to today's outright rejection of all such weapons in any circumstances. During the previous era, those discourses from within the Catholic Church which supported nuclear weapons as deterrents most often focused on the abstract, tending to elide those people who have been negatively affected by atomic weapons, testing or nuclear fallout. This article argues that a little-known suburb of the modern town of Nagasaki has exerted an influence out of the ordinary on the evolving position on nuclear warfare of the Catholic Church. Alternatively, if not the suburb, it is the 'memory of Ground Zero' emanating from here that exerts such influence, which is especially evident when we examine the two popes' visits to Japan. The name of that suburb is Urakami.

For over 250 years after the Christian ban by the powerful Tokugawa shogunate of the early 1600s, the Christian or Hidden Christian community in this semi-rural region of Urakami, north of Nagasaki City, hid their clandestine religious beliefs. Occasionally, the community was disrupted by 崩れ kuzure or 'crushings' as the Nagasaki shogunal magistrate brought down punishments or persecutions upon discovering the ongoing practice of illegal religious activities (Kataoka 1967; Itō 1993, p. 9; McClelland 2019, p. 6). Nevertheless, the Hidden Christians and later Catholics held on to hope of eventual relief in 
their location nearby the harbour town of Nagasaki. Nagasaki was a major port on shipping routes and a place of sporadic encounter with European seafarers and missionaries since the 1500s. A final severe persecution was instituted by the Shogunate and consequently the new Meiji Government from the late 1860s (Kataoka 1963). At last, in 1873, the Christians were freed from exile and consequently established a new centre for worship in Urakami that was christened St. Mary's Cathedral. This church was the biggest in East Asia at the time, in the middle of a farming region outside of Nagasaki City.

Some seventy years later, in 1945, six days prior to the Shōwa Emperor's surrender at the end of the Pacific war, the US army bombed Urakami, now a northern, industrial suburb of Nagasaki, with a plutonium atomic bomb, and this region was destroyed as Ground Zero of the atomic attack, north of Nagasaki city. The bomb killed immediately around 8500 of 12,000 Catholic community members among the wider casualties. Of the Catholics who survived, also known as hibakusha, their memory of this event was imbued by longer memories of persecution and survival, which I will call in this article 'memory of Urakami Ground Zero'. ${ }^{1}$ The memory of Urakami Ground Zero incorporated more than simply the bombing, but also a worldview and communal understanding which remembered the persecution which had come before. This memory would eventually influence the pope(s) and thus the Vatican. One of my interviewees in 2016 in an oral history project carried out in Urakami was Ozaki Tommei. Ozaki was both a hibakusha and a religious in the Catholic community, and he explained that a prophecy remembered by the community was that after seven generations, the arrival of the pope's boat from Rome would herald a new-found freedom for the Christians (Ozaki 2016). The Christians would excitedly welcome the pope.

\section{Memory as Framework}

In the book History and Memory after Auschwitz, Dominick Lacapra writes that while memory may be a dubious phenomenon, nostalgic or sentimental, or a partially fictionalised past conveyed in conventional narrative form, it still poses significant questions to history by directing our vision to engage with problems which are alive and imbued with emotion and value (LaCapra 1998). The Catholic hibakusha themselves exerted a particular power to influence meanings and discourse on nuclear weapons within the World Catholic Church (Ashplant et al. 2015). Some Urakami hibakusha made pilgrimages to the Holy See including Ozaki Tomei. ${ }^{2}$ At the same time, a new readiness among the Catholic hibakusha to speak out about their experiences gradually gathered pace after the 1980s. As a result, and as I will describe below, a change in Catholic discourse in the World Church has emerged about nuclear weapons by the second decade of the twenty-first century. We may understand this by considering how transmitted memories such as those passed on by the hibakusha in Nagasaki are powerful and disruptive, with the potential to open our eyes to human suffering. By centring memory of Urakami Ground Zero in post-atomic Nagasaki, we may indeed find that this community has disrupted an overly abstracted Catholic Church discourse about nuclear weaponry. For Mary Fulbrook (2002), history is not fiction, but nevertheless requires imagination, creativity and critical powers of selection. Maurice Halbwachs writes that religious doctrine is the collective memory of the Church, but also concurs that the theology of a period is partially of that time (Halbwachs 1992, pp. 112, 117). The emerging theology of the Urakami Catholic local church which suffered in the dawn of the atomic age has influenced and directed the World Church's response to nuclear weapons. By understanding the power of memory of Urakami Ground Zero, we may shed light upon a gradual shift in official discourse in the Church about these weapons up until today, as illustrated by reference to the coming of the two papal tours to Urakami.

Even if the prophesied ship from Rome spoken of by Ozaki never did arrive, two popes did eventually visit Nagasaki. Pope John Paul II in 1981 and Pope Francis in 2019 arrived in the city to great fanfare and excitement on the part of the local Catholic Church and community. The visit of Pope John Paul II exerted a considerable influence over 
time on the local community, as was clear from my own interviews conducted in the twenty-first century with hibakusha (McClelland 2019). Drawing on Japanese language oral history sources and a discussion of the literature concerning Catholic discourse on nuclear weapons, this article re-considers the encounter of the two popes of differing eras with the Urakami Catholics. I raise the possibility that these encounters were not only influential in the local community, but that memory of Urakami Ground Zero has served to disrupt and influence an official and predominately abstract Catholic discourse about nuclear weapons by bringing home to the official church, the pope and the Vatican the reality of what occurred there in 1945.

\section{Blessing 'Fat Man'}

Many Christians in the US during World War II supported the mass bombing of German and Japanese cities while churches stayed silent about them for the most part, and although the atomic bombings were criticised, this failed to result in mass protest (Sittser 1997, pp. 176-79). Robert Oppenheimer named an early atomic test 'Trinity', although his concern for the dark side of what had occurred is pointed to by his comments after Hiroshima and Nagasaki, ' . . . these physicists have known sin' (Welty 2016, p. 396). Most ironic is the fact that the atomic bombing which devastated Urakami was officially 'blessed' (Nagasaki was not its original target). Catholic priest, Father George Zabelka, blessed the men who would drop the atomic bomb, nicknamed 'Fat Man', on Urakami.

\section{The 'Holocaust' Theory}

In order to better understand what drove Urakami memory prior to the 1980s, however, let us briefly consider an influential theology of the bombing that arose out of the Japanese Catholic community and that imbued collective memory here. This theology was initially described in November 1945 in the context of a Mass held at the destroyed Urakami Cathedral. Here, a Catholic doctor and hibakusha named Nagai Takashi spoke, his interpretation quickly becoming highly influential in the public narrative for Catholic survivors, although it has been strongly challenged since (Nagai 1949; Diehl 2018). Takahashi Shinji, a Nagasaki philosopher, called Nagai's theologizing about the bomb 'the Holocaust', or burnt-offering theory, because Nagai suggested that those who died in the atomic bombing were an offering to God, and it was providence which led to Urakami being 'chosen' as a victim (Takahashi 1994). Yuki Miyamoto recalls Nagai's stress in his interpretation that the day the emperor announced Japan's surrender, some six days after the atomic bombing, was the feast of the Assumption of the Virgin Mary. Altogether, by this discourse, the sacrifice of the Urakami victims at Nagasaki led to the end of the war (Miyamoto 2012, p. 131). For many among the Urakami Catholics, this understanding, which saw a divine hand in even the atomic bombing, remained a predominant narrative until at least the 1980s. Some with whom I spoke in the late 2010s still supported the 'Holocaust theory' (Takahashi 1994) of Nagai Takashi. However, the Pope's words at Hiroshima would begin to shift this theology of the atomic bomb in the collective consciousness.

I have described elsewhere how the visit of John Paul II had considerable impact on the Urakami community's understanding of their own experiences, by building upon the work in Nagasaki of scholar Shijō, Chie (McClelland 2019; Shijō 2015). My own work around Ground Zero in Urakami involved interviews with nine Catholic hibakusha and other members of the local Christian community conducted between 2014 and 2016. In Catholic hibakusha interviews, the participants voiced a strong sense of irony about the impacts of an 'atomic war' and protested the American figures who supported this action. I discerned through this oral history study a significant shift away from the 'Holocaust theory', leading to an increase in Catholic participation in memorializing since the 50th anniversary of the bombing and the visit of John Paul II. My monograph, Dangerous Memory in Nagasaki, describes how the Catholic hibakusha I interviewed suggested that in recent years and especially post-1981, a new era arrived in which they are included in 
'peace-making', protest and petition against the piling up of nuclear weapons. To better understand how this shift occurred, let us re-examine the first papal visit to this city.

\section{War Is the Work of Humanity}

Early in his Japanese trip in 1981, the Pope directly addressed the topic of nuclear weapons. JP II began his speech in Hiroshima with the words:「戦争は、人間の仕業 です。」Sensō wa, ningen no shiwaza desu. War is the work of humanity. The impact of his words delivered in the Japanese language should not be underestimated, although it is also significant that this memorable statement was not made in Nagasaki. However, considering the importance of Nagai Takashi's providential interpretation of the bombing, the Pope's words resonated and caused a gradual shift within the Catholic community in Nagasaki over time.

Pope John Paul II arrived in Urakami early on a freezing and snowy February day in 1981 after he had already travelled to Hiroshima. In Nagasaki, he first met 2000 religious women in Urakami Cathedral, before going on to the snowy Matsuyama stadium to conduct a Mass. JP II made five speeches at Nagasaki, including one to hibakusha at the Megumi no Oka 'Hill-of-Grace', another as he visited the 26 Martyrs' Museum and another as he prepared to leave Japan (Vatican 2021). It was into the context of memory of Urakami Ground Zero as a 'providential discourse' that John Paul II in 1981 spoke in Japanese in Nagasaki, and the video of his address at the Matsuyama Sports Ground mass is able to be viewed online. Explaining his efforts to learn to speak Japanese, Pope John Paul II related, 'It is because I love the people of Japan and their culture. It is because the heart of a people is found in its language' (Rush 1981, pp. 384-85). On the ground in Nagasaki, however, he did not directly denounce nuclear weaponry. When he spoke with the atomic bomb survivors, hibakusha, he emphasised instead their experiences of suffering, while he quoted the Mayor of Hiroshima rather than any Urakami voices.

\section{The Holy See's Radical Turn to Deterrence and the Cold War}

Despite his 'pilgrimage' to Urakami and expressions of concern for this community, Pope John Paul II in consequent years contributed to the abstract discourse in the World Church about these weapons. Although Pope John Paul II was clear in 1981 in his speech made in Hiroshima that these weapons, which laid low the city of Hiroshima and the Urakami community, were the 'work of humanity', on the other hand, he accepted the stockpiling of at least some of them for the security aim of deterrence. Hyrnkow puts it in this way: 'in what may be read as a concession to the status quo realities of the cold war, John Paul II permitted a small moral space for nuclear deterrence ...' (Hrynkow 2019, p. 65). One year after his visit, in 1982, Pope John Paul II made a speech in the United Nations in which he condemned these weapons but proclaimed they were necessary at least for a temporary period for deterrence. For Senior Research Fellow at NUPS in Budapest, Lorand Ujhazi, Pope John Paul II's speech was a 'radical turn' for the Holy See, which Ujhazi perceives to have been more clearly anti-nuclear in the previous era. On the basis of John Paul II's assertion about deterrence, Catholic security politicians and bishops expressed various views on deterrence and the question of possession of nuclear weapons (Ujhazi 2020). Nuclear war was abstracted, and a clear stance was not evident.

It is notable that in Nagasaki, as opposed to Hiroshima, the pope did not make a direct commentary on nuclear weapons. ${ }^{3}$ In his speech choice in the two cities, JP II likely wished to avoid upsetting sensibilities, especially in the local Catholic community. His avoidance of nuclear weapons discourse in Nagasaki could even have been an implicit acknowledgement of the Japanese proverb which insists that Hiroshima rages (protest) and Nagasaki prays (怒りの広島、祈りの長崎 ikari no Hiroshima, inori no Nagasaki) (Treat 1995; Yamaguchi 2016, p. 302). ${ }^{4}$ While JP II made his statement about atomic weaponry being 'the work of humanity' in Hiroshima, he conducted Holy Mass in Nagasaki and visited the 26 Martyrs' Monument. Fifty-seven thousand people attended the mass at the Matsuyama athletics ground, where he acknowledged Nagasaki's pain and prayers. The Pope 
empathised, ' . . the pain you have endured is known by all the people who live here' (Shijō 2015, p. 172). Between John Paul II's speech in Hiroshima about the atomic age and his visit to Urakami and Nagasaki where he met the hibakusha in 1981, it is unclear as to why he supported a policy of deterrence in his consequential speech at the United Nations in 1982. Perhaps the Pope's stance is most understandable in the context of the ongoing Cold War, which encouraged an abstracted discussion about nuclear weaponry.

The Cold War itself began soon after Nagasaki and Hiroshima were bombed in 1945, as the rise of the communist leadership in the United Soviet Socialist Republic (USSR) led to its status as a major militarised world power. Throughout this period, the US and the USSR stockpiled nuclear weapons, and an abstracted nuclear war discourse dominated Vatican and official Church discussions. Daniel Gerster (2018) examined US and West German Catholic discourses between 1945 and 1990 during the Cold War, including discussions which often approved of nuclear deterrence, resting on 'just war theory', which is an influential tradition traced back to Augustine and Thomas Aquinas and foregrounding common good and justice (Cahill 2019, p. 177). Discussions in both the US and West Germany were heavily influenced during this period by anti-communist sentiment. After the atomic bombings, the Catholic Church made varying responses to the rising threat of atomic and nuclear weaponry. On the margins were figures such as Dorothy Day, who was herself responsible for 'reinsert[ing] Catholic pacifism into modern discourse on war' (Klejment 2009, p. 23), while 'just war' discussions which accepted the use of force in certain conditions dominated official Church discourse (Gerster 2018). The leadership of the Church occasionally stood outright against nuclear weapons. Likely influenced by his personal involvement in de-escalation of the Cuban missile crisis in 1963, Pope John XXIII made a clarion call for a ban on nuclear weapons in the Pacem in Terris, Peace on Earth encyclical (Miyamoto 2005, p. 113; Hrynkow 2019, pp. 58-59).

Contrasting views indicate the extent of the Catholic Church's long-lasting ambivalence about the discourse on nuclear weapons. On the other side of the Pacific from Japan, Catholic involvement in the anti-nuclear movement out of the United States was ambivalent and muted particularly after the Soviet Union developed their own atomic weapons. Some Catholic faithful supported the US Military assumption that any means should be used to battle the communist power. There was commonly a strong belief that the communist power had a dependence on atheistic, materialistic principles. American Jesuit John C. Murray advocated that since nuclear war might be a necessity, it ought to be a possibility, and a West German Jesuit, Gustav Gundlach, openly supported the principle of nuclear deterrence (Gerster 2018, p. 196).

Ultimately, there was a perceived security in abstraction. Gerster argues that 'Catholic thinking about the atomic conflict remained predominately abstract because it considered itself part of the official Catholic discourse'. Gerster describes various 'images of war', anticommunist discourses and conceptions of 'peace' in both West German and US Catholic circles. Another scholar, Brittany Harris (Harris 2020, p. 7), explains that the US Catholic Bishops' pastoral letter of 1983, entitled 'The Challenge of Peace: God's Promise and Our Response', set out a Catholic official stance to the 'problem' of nuclear weapons, largely based upon 'just war theory'. The primary goal and first tenet was for peaceful resolution via diplomacy, with the acknowledgement that some situations would nevertheless require the use of force. While the intentional targeting and killing of innocent citizens and non-combatants was unjustifiable, the bishops argued against the deployment of nuclear weapons. However, they stopped short of advocacy against nuclear weapons in all situations, perhaps in deference to Pope John Paul II's 1982 statement on deterrence. Thus, deterrence was accepted as a moral option, although not a long-term solution (Harris 2020). This statement from the US Bishops, in its acceptance of at least some stockpiling of nuclear weapons as deterrents, conceived of the potentiality of 'imagined' nuclear war. The letter effectively made nuclear weapons an abstraction in the same way the Pope's statement of 1982 accepted them as necessary, albeit as a last resort. 


\section{The Silent Japanese Church}

I argue in this article that one reason for the Catholic Church's abstracted discussions of the issue of nuclear weapons is due to a loss of memory or at least a neglecting of the human experiences of the first atomic bombings in war. In Japan, however, the atomic bombings were close to home. The centring of the atomic bomb on the Catholic region of Nagasaki was, in the 1940s and 1950s, well known, but even here, memories and publicity about Hiroshima gradually outdid that of Nagasaki, and so the socio-religious characteristics of the region which suffered the second atomic bombing, including the Catholic community, were widely forgotten. Even within Japan, writers suggested that the initial singling out of this religious community as predominant victims of the bomb was problematic, with the charge that it excluded the many others also affected (see, for example, Hama et al. 2013).

The discourse on nuclear weapons carried out by Church leaders or local community members was largely abstracted in the World Church, but in Japan and especially in Nagasaki, it was avoided. Memory of Urakami Ground Zero was not often discussed in the Japanese Catholic Church, especially in the influential Nagasaki Archdiocese (at least until the 1980s). Where the little discussion about nuclear weapons actually occurred, at least prior to 1981, it was largely influenced by the wider Vatican official discourse referenced above. Shijō (2015) examined in detail the Catholic discourse in Japan, concluding that until the 1980s, anti-communist rhetoric and their avoidance of politicised discourse led to the Japanese Catholic Church fundamentally avoiding speech about the impacts of the atomic bombing of Urakami (Shijō 2015, p. 180). Before the 1980s, Catholics were in the main uninvolved in peace protests, anti-nuclear campaigns and peace activities at the Nagasaki International Cultural Hall (later called the Nagasaki Atomic Bomb Museum) against the backdrop of the delegitimizing discourse within the Church and the community. There were multiple reasons for the Christian non-involvement in protest against the bomb, some of which resulted from pre-existing tensions. From the 1930s and during the war, Japanese nationalists strongly questioned the loyalties of Christians and other religious groups to the imperial cause. Here, in a very different context, is evidenced a relationship between memory and discourse, but in this case it is an anti-Christian discourse in Japan which I will not enter into here due to limitations of space.

After the Vatican issued a statement supporting shrine visits, the Catholics participated in them post-1931. The faithful also contributed considerable monies to the war effort, and their young men went to assist in the war efforts including on the frontline (Allam 1990, pp. 44-45). Following the war, the Nagasaki Catholics were reticent to be involved in 'political' activities protesting the atomic bombing due to a fear of being called 'aka' (Reds) (Shijō 2015, p. 162). Many in the community traced their ancestors to the 'Hidden Christians' of the nineteenth century, and socially they tended to avoid 'loud protests'. These Catholics believed they might be cast as communists if they should involve themselves in strident protests.

\section{Speaking the Memories}

The pope's speech made not at the mass in Nagasaki, but at the Peace Park in Hiroshima, contributed to a gradual but ongoing transformation of the religious community's interpretation of the memory of the bombing. When John Paul II arrived in Hiroshima on 25 February 1981, and said, 'This [the bomb] is the work of humanity [...]', there was relief among the religious community in Urakami. While he may have contributed to the broad ambivalence of the Church's response to nuclear weaponry, Pope John Paul II indirectly contributed to a new revival of memory in Urakami Ground Zero which displaced the idea of the bomb as 'providential' due to his statement in Hiroshima. A difficulty for many of the faithful was their understanding from Nagai Takashi's theologizing that the atomic bombing should be understood within the doctrine of God's providence. If God, the logic followed, could allow for the bombing, what then could anyone say about the bombing? What then might anyone (even hibakusha) then say about God? (Shijō 2015, 
p. 48). JP II clarified the Divine One was not involved in these atomic bombings: 'War is the work of humanity (ningen no shiwaza); war is destruction of human life; war is death'. The Nagasaki Newspaper reported on 26 February 1981, that after the Hiroshima visit, the Catholic Mayor of Nagasaki, Motoshima Hitoshi, said 'Nagasaki citizens who pray and wish for peace hope that this [statement] will be told to the whole world by the pope' (Shijō 2015, p. 172). As a result, the readiness of the Catholic community to finally speak out and be involved in peace activities must be partially traced to this first papal visit to Japan.

The shift in interpretation was not immediate, however. At the commemoration of the 40th anniversary of the atomic bombing in 1985, the 11th Japan Catholic Justice and Peace Convention ((カトリック正義と平和協議会 (katorikku seigi to heiwa kyougikai) took place over three days in Nagasaki, and the opening speech reprised JP II's words, 'War is the work of humanity. War is death' (Shijō 2015, pp. 183-185). The opening address at the conference included the exhortation to the hibakusha that by speaking of their experiences, they should contribute to Asian and world peace. Later, a hibakusha activist and Catholic Doctor, Akizuki Tatsuichirō, said 'Up until today, you [hibakusha] have not spoken much about your experiences of the atomic bombing. That's because you were afraid of it being used in a political way'. (Shijō 2015, p. 185). He exhorted the Catholic hibakusha to speak out about their experiences. In my own more recent study, multiple community members including Nagai Tokusaburō, grandson of Nagai Takashi, the wellknown Catholic hibakusha, confirmed that the community were significantly impacted by the pope's words (McClelland 2019).

The nun and hibakusha Kataoka Chizuko was another who reflected in her interview in 2016 about the pope's visit of 1981 and the changed attitudes which broke through walls of silence ('walls of silence' is a concept of memory within Nagasaki described in Diehl 2018). ${ }^{5}$

[...] but after the Pope stated 'that' [war is the work of humanity], he said [we] must talk about it [...] This was what changed. [...] There were a whole lot of people who as victims [...] [had experienced this pain of ours] [...] [which] we (jibun-tachi) hadn't talked about it, [pain] concealed within us [...] However, the Pope urged [...] that we had to work more for the sake of world peace, so if the Pope says so, even if it is painful, alright, our experiences should be added to the discussion [...] I think this was the kind of change you see (Kataoka 2016; McClelland 2019, p. 78).

The ongoing changes in the community including involvement in peace activities and protest about the bombing contributed to the healing of psychological scars. Kataoka Tsuyo, a Catholic hibakusha, described to a journalist how she was so shattered by her experience of being injured in the bombing and her facial scarring that she seriously considered committing suicide. It was the coming of the pope in 1981 that signalled her experience of a transformation, so she became a kataribe (storyteller), talking about her experiences and explicitly rejecting the idea of the 'providential' bomb (Tomatsu 1995; Shijō 2015, p. 182).

Gradually breaking free of a theology of providence which had included the bombing, after JP II's visit to Nagasaki, the Catholic community began to outwardly challenge the narrative that the bombing was justified. On the seventieth anniversary of the atomic bombing on 9 August 2015, the Urakami Cathedral which had been destroyed in the bombing was lit up by a light show (the cathedral was rebuilt by 1959), explicitly protesting the bomb, and inside the cathedral, the community displayed a statue of fractured Mary, lent to them by Catholics of Guernica, a symbol of the ruins of 'total war'. Another hibakusha, Matsuo Sachiko, explained in 2014, 'I don't think the United States has understood yet ... we are in pain, it is too painful ... for hibakusha the pain continues and they are disappearing. This feeling is still strong ...' (Matsuo 2014; McClelland 2019, p. 182). For the Catholics of Nagasaki, an outright acknowledgement by the United States of the injustice and inhumanity of the act of the bombing human to human would still, after so many years, be deeply meaningful. In 2016, when I asked Catholic hibakusha Nagase Kazuko about the perpetration of the atomic bombing, she told me: 'This is not something 
one should forgive. The atomic bomb, you mean? I don't forgive it' (Nagase 2016; McClelland 2019, p. 184). The move to protest among the Japanese Catholics may be cause to re-consider for United States constituents (still over $50 \%$ in recent surveys) who continue to claim the atomic bombings were a necessary evil (Stokes 2015).

Many hibakusha explained in interviews how during the years 2014 to 2018, they had become involved in peace activities, teaching school children and leading tour groups in the anti-nuclear movement at the Nagasaki Atomic Bomb Museum. Between the first papal visit in 1981 and the second in 2019, the Urakami hibakusha joined those testifying at the Nagasaki Atomic Bomb Museum, told their stories, went to the United Nations to speak of their experiences and supported a new grass roots campaign for a Treaty on the Prohibition of Nuclear Weapons (TPNW). The TPNW campaign was taken up not only by the Nagasaki hibakusha but also within the Vatican.

The long and bitter experience of the Catholic faithful and their memory of Urakami Ground Zero returned to the fore in the years from the 1980s onward, not forgetting the many non-Catholic hibakusha, including Korean indentured workers (estimated 10,000), burakumin outcasts and the second and third generations who still reap the consequences of that event. As Kataoka's words above indicate, talking about the bombing and protesting about the bombing was not an easy undertaking, but for the 'sake of world peace', she was convinced of its necessity.

\section{Memory's Power}

Pope John Paul II made a great impact in Urakami, but his influence in 1981 was not unidirectional, and memory of Urakami Ground Zero was also in evidence to the pope. It is less easy to discern exactly how the community made a definitive impression on either JP II or on Pope Francis. The popes' visits to Urakami offered two opportunities for the over-abstracted Catholic Church discussion about atomic or nuclear weaponry to be informed by the reality experienced by this specific community. It is largely through the evidence of both popes' personal engagements within the community that we may see the potentiality of the influence of the memory of Urakami Ground Zero. JP II visited the Genbaku Homu (elderly residents' home) on Megumi no Oka, and a video shows him blessing and being greeted by the elderly residents there due to their exposure to the atomic bombing. One of my interviewees, Ozaki, uploaded a photograph on his personal blog of JP II blessing him, when Ozaki visited the Vatican, by placing his hand on Ozaki's head. In the photograph, John Paul II is smiling broadly. Ozaki lived to observe the pilgrimage of Pope Francis when he arrived in Nagasaki on 25 November 2019.

Distinctive in the Urakami Catholic narrative and mentioned by both JP II and Francis in their speeches in Nagasaki is the suffering and trauma which are a part of their memory, stretching back to well before World War II. Both papal visits included a visitation to the 26 Martyrs Museum and monument, the best-known memorial to the martyrdoms of the sixteenth century that was built in 1962. One significant part of the local community's metanarrative is the two and a half centuries when they were separated from the Roman hierarchy. Known as 'Hidden Christians' or Kakure today, while Christianity was banned, these communities hid their faith under a guise of Buddhist or Shinto practice (McClelland 2017). Influences on their ancestors during the sakoku (closed country) period from 1603-1868 included multiple martyrdoms and persecutions as well as sacred sites which acted as mnemonic memorials of suffering. Oral records and religious practices were passed on by word of mouth.

In 2019, Pope Francis, like JP II, officiated at a Mass at Urakami's local baseball stadium (Figure 1), and an A-bombed icon of Mary was placed at the front for all to see, on the same stage as Francis assumed his seat. For the Catholic community, it is not only the memory of Urakami Ground Zero that is evoked by this icon of Mary, but also the comforting symbol of Mary which was a consistent part of faith and practice for their ancestral communities. During sakoku (while Japan was mostly secluded from the West), these communities adopted the gender-ambivalent Kannon Bodhisatva (Guanyin) figure to stand in for Mary, hiding their Christian (or a culturally hybrid) faith under the guise of 
a Buddhist icon (McClelland 2017). Later, when they built their first Cathedral after the 'hidden' period, the Urakami Cathedral was blessed in the name of the Holy Mother.

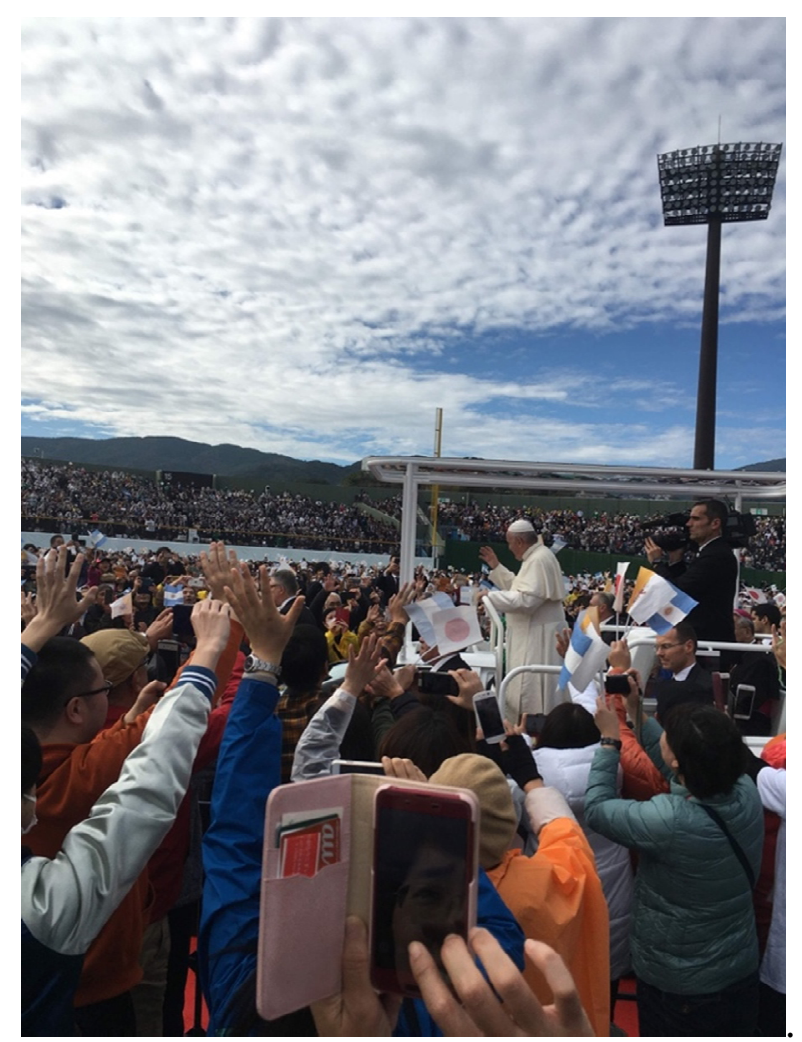

Figure 1. November, 2019, Pope Francis arrives at the stadium Mass, Urakami; photograph, the author.

In addition to the A-bombed Mary which encompasses suffering and compassion is the memory for the Urakami faithful of reconciliatory and blessed encounters with missionaries and foreign priests. Thus, when the Polish Pope John Paul II visited Nagasaki, one important stop was at the Polish-originated Seibo no Kishi (Knights of the Holy Mother) monastery. This monastery is a symbol of hopefulness, as the monks here assisted in the recovery after the atomic bombing, adopting orphans, including the interviewee Ozaki Tōmei, hibakusha, who lost his mother in the bombing and became a monk himself in the Franciscan order (McClelland 2020).

\section{Pope Francis in Urakami}

In 1981, snow; in 2019, rain (Figure 2). I was present in the city for the full period the pope was present there in late November at a time of great rejoicing for the faithful, who thronged here from around Japan. The town flooded with police, many reinforcements arriving from Fukuoka for the visit of the great dignitary, Pope Francis, and choirs practiced at the monuments (Figure 3). Pope Francis visited Nagasaki in late 2019 and reversed the tour of the previous pope by scheduling his visit to Urakami first and only later progressing to Hiroshima. Pope Francis and the Holy See, from at least 2014, clearly admitted the moral problem of the possession of nuclear weapons, even in situations of deterrence (see Clarke 2018). Pope Francis's visit offered an important opportunity to reflect on how much had changed in Catholic Nagasaki, happening just prior to the COVID-19 crisis of 2020. Francis was the first to unambiguously condemn the use of atomic bombs in any situation and to condemn stockpiling of weapons as well. He was already moved by what he knew about the Urakami memory of Ground Zero, as is evident by his sending out postcards in late 2018 including a poignant photograph of the aftermath of the bombing of Urakami. The photograph shows a young boy with the dead body of a baby child slung on his back, 
waiting for a funeral pyre. As the rain poured down in late 2019, I listened alongside the hypocentre (Ground Zero) while the pope spoke in front of a corner of the original ruins of the Urakami Cathedral, relocated here by the City Office in 1958.

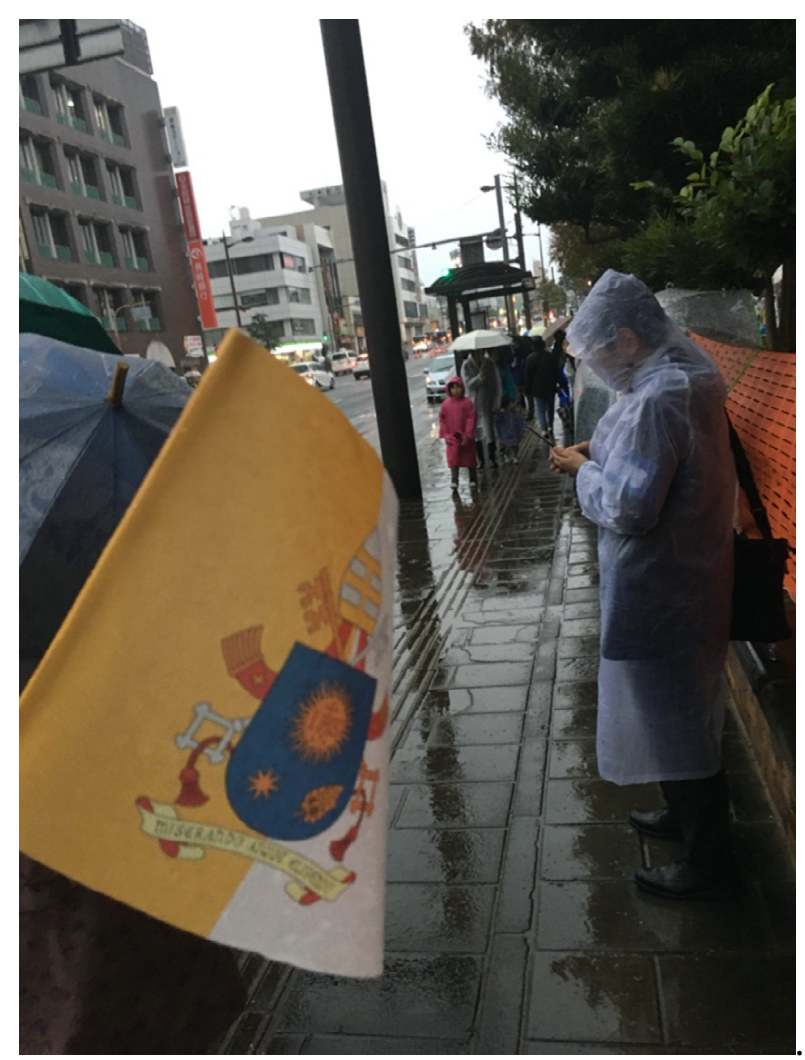

Figure 2. Waiting in the downpour for Pope Francis, 2019; photograph, the author.

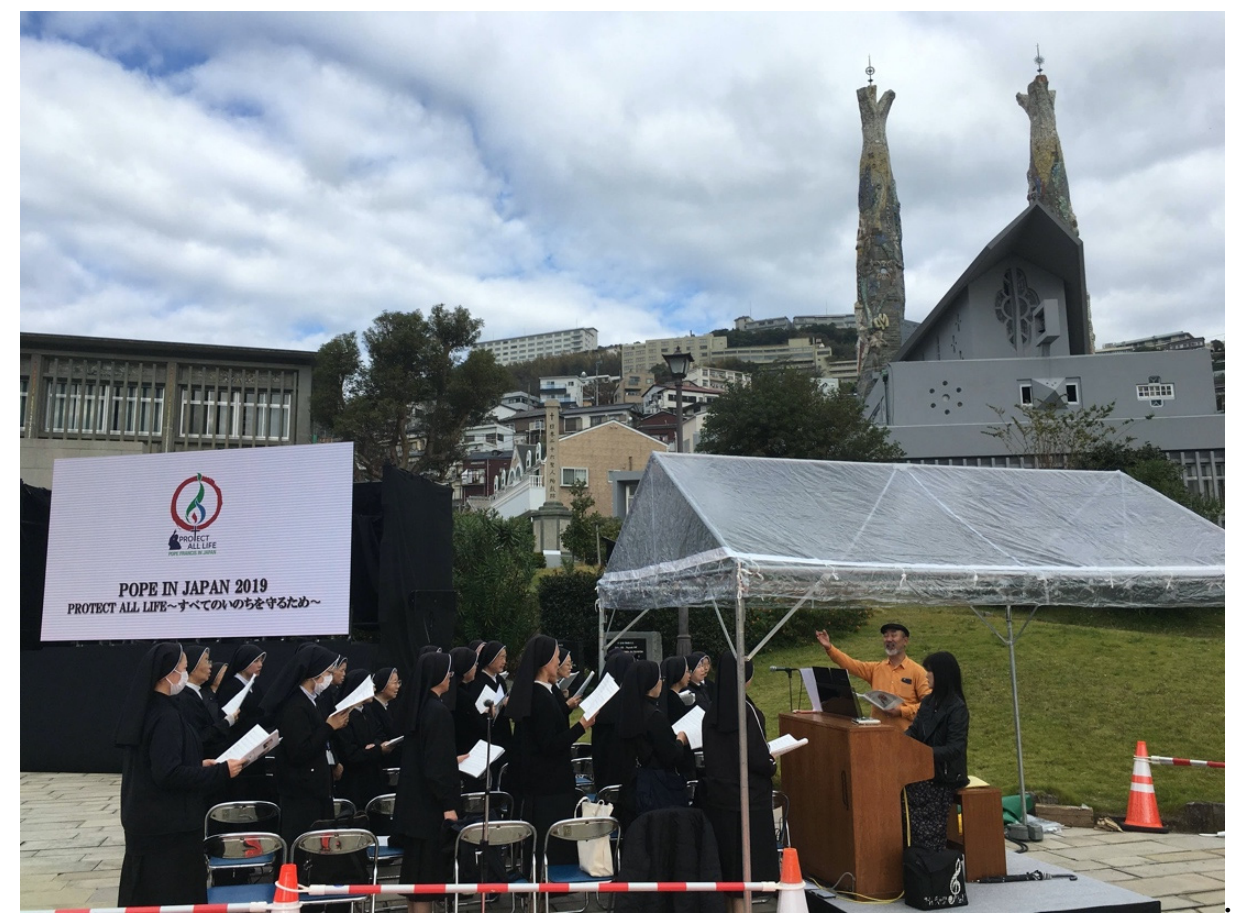

Figure 3. Preparing for Pope Francis's coming, 26 Martyrs Monument, Nishizaka, November 2021; photograph, the author. 
While JP II had avoided any speech against nuclear weapons here, the way had by now been exemplified by the local Catholics to protest the bombing. Pope Francis, therefore, in speaking out in what was reported as a strong message against nuclear weapons at the 'hypocentre' site, Ground Zero, was not the first to do so, but followed the local Catholics in this stance. Pope Francis stated, 'Peace and international stability are incompatible with attempts to build upon the fear of mutual destruction or the threat of total annihilation' (Apostolic 2019). He was also welcomed here by Fukahori Shigemi, who spoke on behalf of the Catholic hibakusha.

A Jesuit (like the first missionaries to Japan) and an Argentinian, Pope Francis's presence was well received. At the mass the suffering 'A-bombed Mary' icon from Urakami Cathedral was a powerful symbol of the memory of Urakami Ground Zero; past atomic and persecution suffering; and a reminder of a new path of protest.

\section{Conclusions}

Upon Pope John Paul II's visit to Japan, he carefully avoided protest in Nagasaki, reserving it solely for 'raging' Hiroshima. Nonetheless, on the basis of JP II's speech in Hiroshima, a shift in the Urakami community of both memory and discourse is evident, as the Urakami Catholic believers began during the 1980s to talk at last about their experiences and to be involved in both peace movements and protest. Following Pope John Paul II's visit to Nagasaki, the protests, laments and memories of the suffering Catholic community were more and more pronounced and they openly critiqued the atomic bomb. In terms of the World Catholic discourse on nuclear weaponry, however, despite his trip to Japan, JP II, by a speech made the following year at the United Nations, contributed to an ongoing ambivalence which the Catholic Church has shown about nuclear weaponry through much of the atomic age.

In this article, I traced how Catholic official language about nuclear weaponry between 1945 and 2014 was largely ambivalent, fearful of the communist 'other' and quickly ready to accept the stockpiling of weapons as a necessary evil. However, memory of Urakami Ground Zero, not only the bombing, but a metanarrative informed by this community's long experiences separate from Rome, was made more explicit in the localised and international public record, especially as the two popes visited this place. Additionally, the arrival of JP II in Nagasaki opened up a relationship which was added to by consequent encounters with hibakusha, including interviewee Ozaki Tomei who travelled to and was welcomed in Rome. While Pope John Paul II's considerable influence upon the Catholics of Nagasaki has been noted previously, this article has attempted to weigh up the extent to which the pope, the Vatican and the World Church's nuclear discourse was itself impacted in many ways such as by encounters with hibakusha and the memory of Urakami Ground Zero. The influence of the experiences, protest and narrations of the Catholic church of Urakami upon the pope(s) or upon Church dogma and theology are less certain, yet in the period between the two papal visits, the changes are evident.

An indication of the importance of a developing relationship between the memory of Urakami Ground Zero and the Catholic Church dogma on nuclear weapons is found in the sentiment of Pope Francis when he sent out to the faithful in 2018 a postcard of the devastation in Nagasaki to implore a campaign to decry nuclear weapons. After thirty years of growing Urakami Catholic protest, Pope Francis and the Holy See altered their discussion around nuclear weapons to reject any use, development, or stockpile of nuclear weapons and to give outright support to the new and developing Treaty on the Prohibition of Nuclear Weapons (2021). This major development will have an ongoing impact upon international law, and the relationship of religion to peace, war and power. The results of Pope Francis's visit to Nagasaki might well be further studied in the future to examine their ongoing impacts, if any, on future protest about the atomic bombing, even as the eyewitnesses are increasingly no longer with us.

The discussion touched upon within this article raises ongoing questions about the relationship between the phenomena of memory and discourse. Attention to memory and 
discourse in a globalised religious organisation is affected by socio-political conditions, but it also exerts pressure and is influenced by experience from within. Just as Catholic hibakusha testimony draws on individual and communal memories and narratives, the priest embedded in the US army who blessed the weapon, 'Fat Man', did so in a context rooted in his own experiences, relationships and memory. Ongoing discussions of the intricate inter-relationship of memory and discourse in similar contexts and how they are supported, disrupted or influenced will be valuable in religious studies and theology. ${ }^{6}$

It might well be argued that the influence of the Vatican on world peace is waning, as the Church's authority is challenged for valid reasons on local, national and world stages. In this case, though, the stance of the Holy See will continue to be a significant one for nuclear diplomacy in a world in which a division is delineated between militarised, wealthy nations with nuclear capabilities and non-militarised, smaller nations that strongly support the new Treaty on the Prohibition of Nuclear Weapons. While nuclear stockpiles have mostly reduced since the 1990s, governments such as the United States continue to plan a role for their armaments into the future, and the British government has recently discussed and inscribed a future increase in their nuclear arsenal. Whatever the case, the religious ironies of the United States' 'Christian' blessing in wartime of the nicknamed bomb 'Fat Man', then being deployed on the largest Christian community in Japan, are stark. This weapon was indiscriminate-a weapon of mass destruction. It was the most vulnerable and exposed human communities, including the oppressed Catholics of Nagasaki (and the Korean interned workers and outcasted communities), for whom the results of this bombing were the most devastating. May the memory of Urakami Ground Zero continue to inform not only the Worldwide Catholic communion, but also other states, networks, and religious, political and social organisations about the importance of anti-nuclear diplomacy for the future of human co-existence.

Funding: This research received no external funding.

Institutional Review Board Statement: Not applicable.

Informed Consent Statement: Informed consent was obtained from all subjects involved in the referenced study.

Data Availability Statement: Not applicable.

Acknowledgments: I would like to acknowledge the anonymous reviewers' astute comments which assisted me greatly in developing the final article. I would in particular like to thank Rosemary Callingham, HASSE Research office at the University of New England, Australia, and the Editors of the Special Issue for their reflective advice and reading of the drafts.

Conflicts of Interest: The author declares no conflict of interest.

\section{Notes}

1 In this article, by the use of the Japanese term hibakusha, I deliberately avoid usage of the term 'bomb survivor' as it can tend to limit the person denoted by the single experience. I considered the possibility of using the term sufferer, but would like to also thank the anonymous reviewer who reminded me of the criticism of Robert Jay Lifton for framing the hibakusha as 'Death in Life' by the hibakusha themselves, who were adamant they were not dead. The Japanese term hibakusha has a broader meaning around those exposed to the atomic bombing, which includes those who died, were exposed to radiation and were eyewitnesses (Lifton 1991). Therefore, I have used the term hibakusha throughout.

2 As is described on a blogpost in 2019, including a photograph of Ozaki and Pope John Paul II. Tōmei Ozaki, ‘Kinou Ha 'Kyoukou Yohane Pauro Nise' No Hi. Machikogareta Papasama,' Ozaki Tomei No 93sai Nikki (blog), 23 October 2019, https:/ / tomaozaki.blogspot.com/2019/10/blog-post_23.html. (Ozaki 2019).

3 For this analysis, I analysed all of the five speeches given by John Paul II in Nagasaki as included on the Vatican website: 'Meeting with women religious', 'Visit to the Hill of Martyrs', 'Visit to the town of the Immaculate', 'Meeting with surviving atomic bomb victims', and 'Farewell ceremony from Japan'. https://www.vatican.va/content/john-paul-ii/en/speeches/1981/february. index.html, accessed 17 September 2021. The Pope's words at the Mass at Matsuyama sports ground are not included on the Vatican website, although a segment of his speech is viewable online. Shijō Chie reports the Pope's address in her book published in Japanese in 2015 (p. 172). 
I do not intend to imply in any way that the pope had a background understanding of this proverb and its origins, but simply that he was advised by Japanese church officials who did.

5 Chad Diehl has written extensively about 'walls of silence' evident in Nagasaki and how they were broken through in the years after the atomic bombing. See his monograph to read more on this, 'Resurrecting Nagasaki', and especially Chapter 5.

6 Thank you to Yuki Miyamoto for raising this salient comment.

\section{References}

Allam, Cheryl M. 1990. The Nichiren and Catholic Confrontation with Japanese Nationalism. Buddhist-Christian Studies 10: $35-84$. [CrossRef]

Apostolic. 2019. Apostolic Journey of His Holiness Pope Francis to Thailand and Japan: Address of the Holy Father on Nuclear Weapons. Available online: https://www.vatican.va/content/francesco/en/speeches/2019/november/documents/papafrancesco_20191124_messaggio-arminucleari-nagasaki.html (accessed on 24 November 2019).

Ashplant, T. G., Graham Dawson, and Michael Roper, eds. 2015. The Politics of War Memory and Commemoration. London: Routledge.

Cahill, Lisa Sowle. 2019. Just War, Pacifism, Just Peace, and Peacebuilding. Theological Studies 80: 169-85. [CrossRef]

Clarke, Kevin. 2018. Dialogue of disarmament: Under Pope Francis the Church Turns on Nuclear Deterrence. Available online: https:// www.thefreelibrary.com/Dialogue+of+disarmament\%3A+Under+Pope+Francis+the+church+turns+on...-a0553760557 (accessed on 28 October 2021).

Diehl, Chad. 2018. Resurrecting Nagasaki: Reconstruction and the Formation of Atomic Narratives. Ithaca: Cornell University Press.

Fulbrook, Mary. 2002. Historical Theory. Thames: Taylor and Francis Group.

Gerster, Daniel. 2018. How to Bring about 'Peace on Earth'?: Catholic 'moralities of Warfare' and Their Shifts after 1945. Interdisciplinary Journal for Religion and Transformation 4: 164-88. [CrossRef]

Halbwachs, Maurice. 1992. On Collective Memory. Lewis Coser (Transl). Chicago: University of Chicago Press.

Harris, Brittany A. 2020. Christian Thought and the Moral Permissibility of Nuclear Weapons. Comparative Strategy 39: 1-17. [CrossRef]

Hama, Hideo, Ken Arisue, and Eiki Takemura. 2013. Hibakusha Chosa wo yomu: Hiroshima/Nagasaki no keisho. Tokyo: Keio Kijuku Daigaku Shuppankai.

Hrynkow, Christopher. 2019. 'Nothing but a False Sense of Security': Mapping and Critically Assessing Papal Support for a World Free from Nuclear Weapons. Journal for Peace and Nuclear Disarmament 2: 51-81. [CrossRef]

Itō, Akihiko. 1993. Genshiya no 'Yobu ki': Katsute kakusenso ga atta. Tokyo: Komichi Shobō.

Kataoka, Yakichi. 1967. Kakure kirishitan: Rekishi to minzoku. Tokyo: NHK bukkusu.

Kataoka, Yakichi. 1963. Urakami yonban kuzure: Meiji seifu no kirishitan dan'atsu. Tokyo: Chikuma Shobō.

Kataoka, Chizuko. 2016. Interview with Gwyn McClelland. Megumi no Oka, Nagasaki. March 1.

Klejment, Anne. 2009. The Spirituality of Dorothy Day's Pacifism. U.S. Catholic Historian 27: 1-24. [CrossRef]

LaCapra, Dominick. 1998. History and Memory After Auschwitz, 1st ed. Ithaca: Cornell University Press.

Lifton, Robert Jay. 1991. Death in Life: Survivors of Hiroshima. Chapel Hill: The University of North Carolina Press.

Matsuo, Sachiko. 2014. Interview with Gwyn McClelland. Nagasaki Atomic Bomb Museum, Urakami. December 12.

McClelland, Gwyn. 2020. Mary, Mothers, Lament, and Feminist Theology: The Dead Non-War Heroes of Nagasaki. Journal of Feminist Studies in Religion 36: 85-106. [CrossRef]

McClelland, Gwyn. 2019. Dangerous Memory in Nagasaki: Prayers, Protests and Catholic Survivor Narratives. London: Routledge.

McClelland, Gwyn. 2017. The Mother of Sorrows as Hibakusha. In Representations of the Blessed Virgin Mary in World Literature and Art, 1st ed. Edited by Elena V. Shabliy. London: Lexington Books, pp. 111-32.

Miyamoto, Yuki. 2012. Beyond the Mushroom Cloud: Commemoration, Religion, and Responsibility after Hiroshima. New York: Fordham University Press.

Miyamoto, Yuki. 2005. Rebirth in the Pure Land or God's Sacrificial Lambs? Religious Interpretations of the Atomic Bombings in Hiroshima and Nagasaki. Japanese Journal of Religious Studies 32: 131-59. [CrossRef]

Nagai, Takashi. 1949. Nagasaki no kane. Tokyo: San Pauro.

Nagase, Kazuko. 2016. Interview with Gwyn McClelland, Genbaku Retirement Home. Megumi no Oka, Nagasaki. March 1.

Ozaki, Tōmei Kinou Ha. 2019. 'Kyoukou Yohane Pauro Nise' No Hi. Machikogareta Papasama. (Blog). Available online: https: // tomaozaki.blogspot.com/2019/10/blog-post_23.html (accessed on 23 October 2019).

Ozaki, Tōmei. 2016. Interview with Gwyn McClelland, Franciscan Nursing Home. Sasaki, Nagasaki. February 27.

Rush, Robert T. 1981. 'His Warmth Came Through': The Pope in Japan. America 144: 384-85.

Shijō, Chie. 2015. Urakami No Genbaku No Katari: Nagai Takashi Kara Rōma Kyōkōe. Tōkyō: Miraisha.

Sittser, Gerald L. 1997. Cautious Patriotism: American Churches and the Second World War. Chapel Hill: University of Northern Carolina Press.

Stokes, Bruce. 2015. 70 Years after Hiroshima, Opinions Have Shifted on Use of Atomic Bomb. Pew Research Center. (Blog). Available online: https:/ / www.pewresearch.org/fact-tank/2015/08/04/70-years-after-hiroshima-opinions-have-shifted-onuse-of-atomic-bomb/ (accessed on 22 September 2021).

Takahashi, Shinji. 1994. Nagasaki ni atte tetsugakusuru: Kakujidai no shi to sei. Tokyo: Hokuju Shuppan.

Tomatsu, Shōmei. 1995. Nagasaki 11:02, August 9, 1945, 1st ed. Photographs by Shomei Tomatsu. Tokyo: Shinchosha.

Treat, John Whittier. 1995. Writing Ground Zero: Japanese Literature and the Atomic Bomb. Chicago: University of Chicago Press.

Ujhazi, Lorand. 2020. Nuclear Deterrence in the Reflections o the Catholic Church Acta. Iustum Aequum Salutare 16: 105-20. 
Vatican. 2021. Speeches 1981 February, Vatican Website. Available online: https://www.vatican.va/content/john-paul-ii/en/ speeches/1981/february.index.html (accessed on 17 September 2021).

Welty, Emily. 2016. The Theological Landscape of the Nuclear Nonproliferation Treaty: The Catholic Church, the World Council of Churches and the Bomb. Global Policy 7: 396-404. [CrossRef]

Yamaguchi, Kenichirō. 2016. Kokusaku to Gisei: Gembaku Gempatsu Soshite Gendai Iriyou No Yukue. Tokyo: Shakai Hyōronsha. 